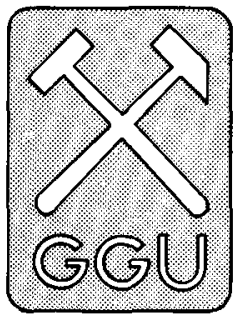

\title{
Publications of the Geological Survey of Greenland 1991
}

\section{Maps in series}

Sheet 5 Thule. Geological map of Greenland, 1:500 000 . 1991 compiled by P. R. Dawes.

Sheet 71 V.1 Nord. Svartenhuk. Geological map of Greenland, 1:100 000. 1991 compiled by J. G. Larsen \& J. Grocott.

\section{Bulletins (Bull. Grønlands geol. Unders.)}

160 Sedimentary basins of North Greenland. 1991 edited by J. S. Peel \& M. Sønderholm. 164 pp.

161 Functional morphology, evolution and systematics of Early Palaeozoic univalved molluscs. 1991 by J. S. Peel. $116 \mathrm{pp}$.

\section{Reports (Rapp. Grønlands geol. Unders.)}

149 Reservoir evaluation of Upper Permian buildups in the Jameson Land basin, East Greenland. 1991 by L. Stemmerik. 23 pp.

150 Current research. 1991.43 pp. (5 articles)

151 A stratigraphic section through the Silurian turbidite sequence (Peary Land Group) in northern Nyeboe Land, North Greenland. P.-H. Larsen \& J. C. Escher. 21 pp.

152 Current research including Report of Activities, 1990. 1991 edited by A. K. Higgins \& M. Sønderholm. 111 pp. (23 articles)

\section{Open File Series}

91/1 Magmatic platinum-nickel occurrences in the Tertiary West Greenland Basalt Province: prospecting by Greenex A/S in 1985-1988. 1991 by F. Ulff-Møller. 37 pp.

91/2 Occurrences of kimberlite, lamproite and ultramafic lamprophyre in Greenland. 1991 by L. M. Larsen. 36 pp.

91/3 The Isua iron ore deposit at Isukasia, West Greenland. 1991 by P. W. U. Appel. 37 pp.

91/4 The Ivigtut cryolite deposit in South Greenland. Short note on recent geoscientific developments. 1991 by J. Bondam. 29 pp.

91/5 Gold and base metal potential of the Îngia area, central West Greenland. 1991 by B. Thomassen. 115 pp.

91/6 A preliminary seismic study of part of the pre-Paleocene section offshore southern West Greenland between $66^{\circ} \mathrm{N}$ and $68^{\circ} \mathrm{N} .1991$ by T. G. Ottesen. 28 pp., 7 maps in folder.
91/7 Oil seep in basement, Germania Land, North-East Greenland. 1991 by F. G. Christiansen, J. Bojesen-Koefoed, S. M. Jensen \& L. Stemmerik. 18 pp.

91/8 Reconnaissance geochemical exploration of map sheet $67 \mathrm{~V} 2\left(67^{\circ}\right.$ to $68^{\circ} \mathrm{N}, 49^{\circ} 30^{\prime}$ to $\left.52^{\circ} \mathrm{W}\right)$, West Greenland. 1991 by A. Steenfelt \& E. Dam. 10 pp.

91/9 Reconnaissance geochemical mapping of southern West Greenland from $62^{\circ} 30^{\prime} \mathrm{N}$ to $64^{\circ} 00^{\prime} \mathrm{N}-1991$ results. 1991 by P. Erfurt, A. Steenfelt \& E. Dam. 21 pp.

\section{Scientific articles}

Bevins, R. E., Robinson, D. \& Rowbotham, G. 1991: Compositional variations in mafic phyllosilicates from regional lowgrade metabasites and application of the chlorite geothermometry. J. metamorph. Geol. 9, 711-721.

Bevins, R. E., Rowbotham, G. \& Robinson, D. 1991: Zeolite to prehnite-pumpellyite facies metamorphism of the late Precambrian Zig-Zag Dal Basalt Formation, eastern North Greenland. Lithos 27, 155-165.

Brooks, C. K., Larsen, L. M. \& Nielsen, T. F. D. 1991: Importance of iron-rich tholeiitic magmas at divergent plate margins: a reappraisal. Geology 19, 269-272.

Chadwick, B. \& Friend, C. R. L. 1991: The high-grade gneisses in the south-west of Dove Bugt: an old gneiss complex in a deep part of the Caledonides of North-East Greenland. Rapp. Grønlands geol. Unders. 152, 103-111.

Chalmers, J. A. 1991: New evidence on the structure of the Labrador Sea/Greenland continental margin. J. geol. Soc. Lond. 148, 899-908.

Chalmers, J. A. \& Dahl-Jensen, T. 1991: Project SYD VEST SEIS - $3285 \mathrm{~km}$ of multichannel seismic data acquired on the southern West Greenland shelf. Rapp. Grønlands geol. Unders. 152, 21-23.

Christiansen, F. G., Piasecki, S. \& Stemmerik, L. 1991 [issued 1992]: Petroleum resources, North Greenland. In Trettin, H. P. (ed.) Geology of the Innuitian orogen and arctic platform of Canada and Greenland, 525-529. Geology of Canada, no. 3, Chapter 20 (also Geology of North America, Vol. E). Calgary: Geological Survey of Canada.

Christie, R. L. \& Dawes, P. R. 1991 [issued 1992]: Geographic and geological exploration. In Trettin, H. P. (ed.) Geology of the Innuitian orogen and arctic platform of Canada and Greenland, 7-25. Geology of Canada, no. 3, Chapter 2 (also Geology of North America, Vol. E). Calgary: Geological Survey of Canada.

Conradsen, K., Ersbøll,B. K. \& Thyrsted,T. 1991: Discrimi- 
nant analysis of an integrated data base applied in uranium exploration. Econ. Geol. 86, 377-386.

Dawes, P. R. 1991: Lauge Koch: Pioneer geo-explorer of Greenland's far north. Earth Sci. Hist. 10, 130-153.

Dawes, P. R. \& Christie, R. L. 1991 [issued 1992]: Geomorphic regions. In Trettin, H. P. (ed.) Geology of the Innuitian orogen and arctic platform of Canada and Greenland, 29-56. Geology of Canada, no. 3, Chapter 3 (also Geology of North America, Vol. E). Calgary: Geological Survey of Canada.

Ellitsgaard-Rasmussen, K. 1991: Arne Noe-Nygaard, 30/7/ 1908 - 3/6/1991. Rapp. Grønlands geol. Unders. 152, 9-10.

Escher, J. C. 1991: The Skjoldungen map sheet: completion of the 1:500 000 geological mapping of South-East Greenland. Rapp. Gronlands geol. Unders. 152, 30-31.

Friderichsen, J. D., Gilotti, J. A., Henriksen, N., Higgins, A. K., Hull, J. M., Jepsen, H. F. \& Kalsbeek, F. 1991: The crystalline rocks of Germania Land, Nordmarken and adjacent areas, North-East Greenland. Rapp. Grønlands geol. Unders. 152, 85-94.

Funder, S. \& Weidick, A. 1991: Holocene boreal molluscs in Greenland - palaeooceanographic implications. Palaeogeogr. Palaeoclimat. Palaeoecol. 85, 123-135.

Garde, A. A. 1991: Post-kinematic diorite intrusions in Archaean basement rocks around outer Fiskefjord, southern West Greenland. Bull. geol. Soc. Denmark 39, 167-177.

Garde, A. A., Bugnon, C. \& Gothenborg, J. 1991: Ornamental stones in West and South Greenland. Rapp. Grønlands geol. Unders. 152, 50-55.

Ghisler, M. 1991: Review of the Survey's activities in 1990. Rapp. Grønlands geol. Unders. 152, 7-8.

Håkansson, E., Heinberg, C. \& Stemmerik, L. 1991: Mesozoic and Cenozoic history of the Wandel Sea Basin area, North Greenland. Bull. Gronlands geol. Unders. 160, 153-164.

Henriksen, N. 1991: The North-East Greenland project 19881990. Rapp. Grønlands geol. Unders. 152, 24-29.

Henriksen, N. \& Higgins, A. K. 1991: The North Greenland Project. Bull. Grønlands geol. Unders. 160, 9-24.

Higgins, A. K. \& Soper, N. J. 1991 [issued 1992]: Metamorphism. In Devonian - Early Carboniferous deformation and metamorphism, North Greenland. In Trettin, H. P. (ed.) Geology of the Innuitian orogen and arctic platform of Canada and Greenland, 289-290. Geology of Canada, no. 3, Chapter 11 (also Geology of North America, Vol. E). Calgary: Geological Survey of Canada.

Higgins, A. K., Ineson, J, R., Peel, J. S., Surlyk, F. \& Sønderholm, M. 1991 [issued 1992]: Cambrian to Silurian basin development and sedimentation, North Greenland. In Trettin, H. P. (ed.) Geology of the Innuitian orogen and arctic platform of Canada and Greenland, 111-161. Geology of Canada, no. 3, Chapter 7 (also Geology of North America, Vol. E). Calgary: Geological Survey of Canada.

Canada, no. 3, Chapter 7 (also Geology of North America, Vol. E). Calgary: Geological Survey of Canada.

Higgins, A. K. 1991: North Greenland glacier velocities and calf ice production. Polarforschung 60 [for 1990], 1-23, 15 figs.
Higgins, A. K., Ineson, J. R., Peel, J. S., Surlyk, F. \& Sønderholm, M. 1991: Lower Palaeozoic Franklinian Basin of North Greenland. Bull. Grønlands geol. Unders. 160, 71139.

Holdsworth, R. E. \& Strachan, R. A. 1991: Interlinked system of ductile strike slip and thrusting formed by Caledonian sinistral transpression in northeastern Greenland. Geology 19, 510-513.

Hougaard, G., Jepsen, H. F. \& Neve, J. K. 1991: GGU's photogeological laboratory - a valuable geological mapping tool in Greenland. Rapp. Grønlands geol. Unders. 152, 32-35.

Kalsbeek, F. 1991: Metasomatic alteration of dolerite in the Proterozoic sediments of north-eastern Disko Bugt. Rapp. Grønlands geol. Unders. 150, 33-35.

Knudsen, C. 1991: Petrology, geochemistry and economic geology of the Qaqarssuk carbonatite complex, southern West Greenland. Monogr: Ser. Miner. Deposits 29, 110 pp.

Knudsen, C. \& Buchardt, B. 1991: Carbon and oxygen isotope composition of carbonates from the Qaqarssuk Carbonatite Complex, southern West Greenland. Chem. Geol. (Isotope Geosci. Sect.) 86, 263-274.

Lane, P. D. \& Siveter, D. J. 1991: A Silurian trilobite fauna dominated by Calymene from Kap Tyson, western North Greenland. Rapp. Grønlands geol. Unders. 150, 5-14.

Larsen, H. C., Sawyer, D. S. \& NARM-DPG 1991: North Atlantic Rifted Margins Detailed Planning Group Report (Executive summary). JOIDES J. 17(2), 24-26.

Larsen, L. M. 1991: Registration of kimberlites and other potentially diamond-bearing rocks in Greenland. Rapp. Gronlands geol. Unders. 152, 61-65.

Larsen, P.-H. \& Bengaard, H.-J. 1991: Devonian basin initiation in East Greenland: a result of sinistral wrench faulting and Caledonian extensional collapse. J. geol. Soc. Lond. 148, 355-368.

Larsen, P.-H. \& Olsen, H. 1991: The Devonian basin project, North-East Greenland - a summary. Rapp. Grønlands geol. Unders. 152, 17-20.

Nielsen, T. F. D. \& Brooks, C. K. 1991: Generation of nordmarkitic melts by melting of basement gneisses: the Astrophyllite Bay complex, Kangerdlugssuaq. Bull. geol. Soc. Denmark 38, 161-164.

Nilsson, I., Håkansson, E., Madsen, L., Pedersen, S. A. S. \& Stemmerik, L. 1991: Stratigraphic significance of new fusulinid samples from the Upper Palaeozoic Mallemuk Mountain Group, North Greenland. Rapp. Grønlands geol. Unders. 150, 29-32

Olsen, T. \& Pedersen, G. K. 1991: The occurrence of marine fossils in the Upper Cretaceous deltaic sediments at Pautût, central East Greenland. Bull. geol. Soc. Denmark 39, 111122.

Peel, J. S. 1991: Functional morphology of the Class Helcionelloida nov., and the early evolution of the Mollusca. In Simonetta, A. \& Conway Morris, S. (ed.) The early evolution of Metazoa and the significance of problematic taxa, 157-177. Cambridige University Press \& University of Camerino (Italy). 

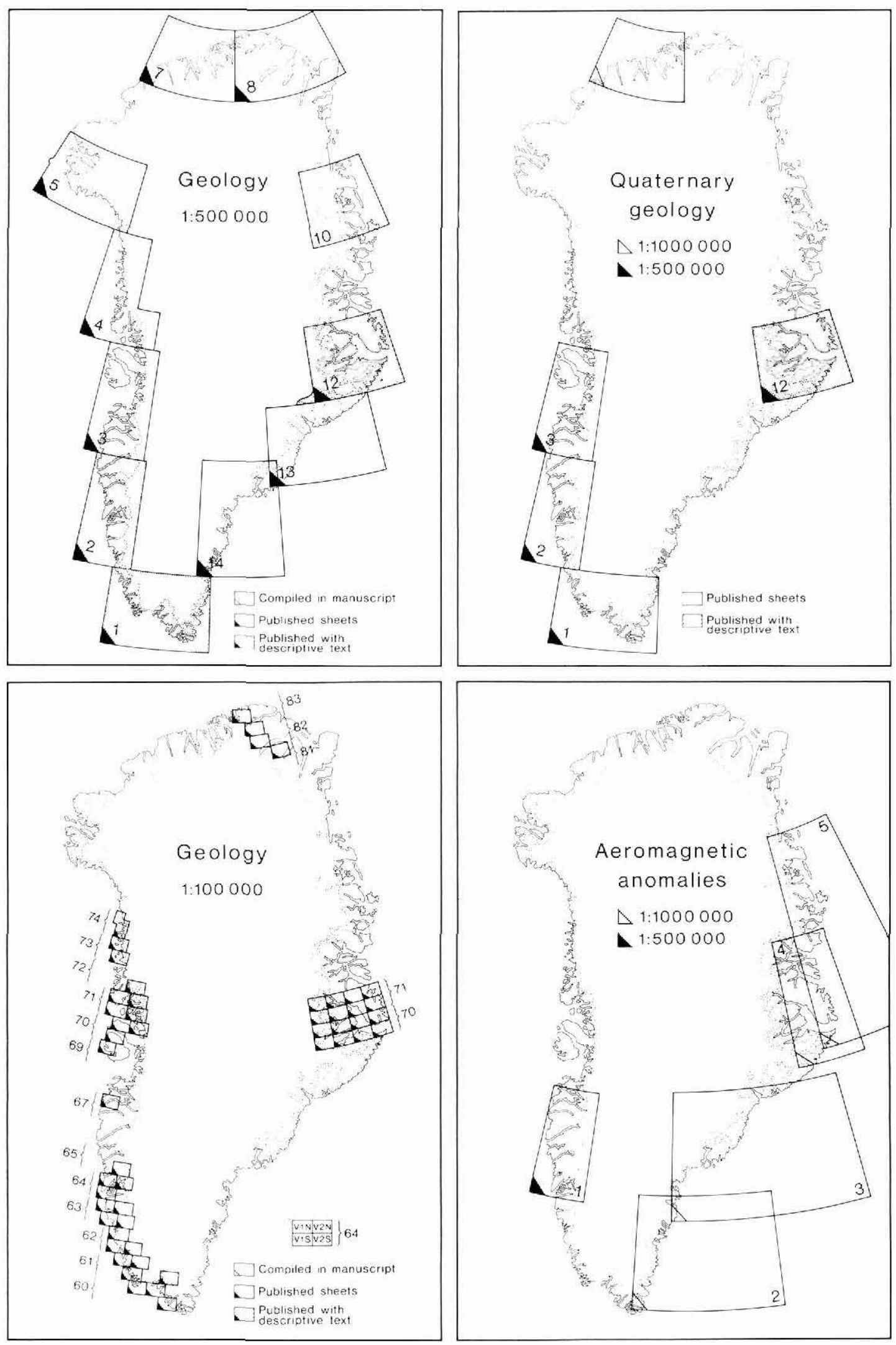

Fig. 1. Map sheets published and in preparation by the Survey. 
Peel, J. S. 1991: Introduction [to Functional morphology, evolution and systematics of Early Palaeozoic univalved molluscs]. Bull. Grønlands geol. Unders. 161, 5-10.

Peel, J. S. 1991: The Classes Tergomya and Helcionelloida, and early molluscan evolution. Bull. Grønlands geol. Unders, 161, 11-65.

Peel, J. S. 1991: Salpingostomatiform and related bellerophontacean gastropods from Greenland and the Baltic region. Bull. Grønlands geol. Unders. 161, 67-116.

Peel, J. S. \& Sønderholm, M. 1991: Introduction [to Sedimentary basins of North Greenland]. Bull. Grønlands geol. Unders. 160, 5-7.

Piasecki, S. \& Stemmerik, L. 1991: Late Permian anoxia in central East Greenland. In Tyson, R. V. \& Pearson, T. H. (ed.) Modern and ancient continental shelf anoxia. Spec. Publ. geol. Soc. Lond. 58, 275-290.

Pickerill, R. K. \& Peel, J. S. 1991: Gordia nodosa isp. nov. and other trace fossils from the Cass Fjord Formation (Cambrian) of North Greenland. Rapp. Grønlands geol. Unders. 150, 15-28.

Pulvertaft, T. C. R. 1991: 1990 - a year of change in hydrocarbon-geological activities at the Geological Survey of Greenland. Rapp. Gronlands geol. Unders. 152, 11-13.

Roberts, D., Coffin, M. F., Crane, K., Eldholm, O., Harry, D., Larsen, H. C., McNutt, M., Okay, N., Pedersen, T., Skoggseid, J. \& Tucholke, B. 1991: Conjugate volcanic passive margin and oceanic plateau development. In Coffin, M. F. \& Eldholm, O. (ed.) Large igneous provinces: JOI/USSAC Workshop Report. The University of Texas at Austin Institute for Geophysics, Technical Report 114, 29-46.

Scholle, P. A., Stemmerik, L. \& Ulmer, D. S. 1991: Diagenetic history and reservoir potential of Upper Permian carbonate buildups, Wegener Halvø area, Jameson Land basin, East Greenland. Bull. Amer. Ass. Petrol. Geol. 75, 701-725.

Schønwandt, H. K. 1991: Economic mineral resources: activities in 1990. Rapp. Grønlands geol. Unders. 152, 41-46.

Smith, M. P. 1991: Early Ordovician conodonts of East and North Greenland. Meddr Grønland, Geosci. 26, 81 pp.

Soper, N. J. \& Higgins, A. K. 1991 [issued 1992]: Deformation. In Devonian - Early Carboniferous deformation and metamorphisn, North Greenland. In Trettin, H. P. (ed.) Geology of the Innuitian orogen and arctic platform of Canada and Greenland, 283-288. Geology of Canada, no. 3, Chapter 11 (also Geology of North America, Vol. E). Calgary: Geological Survey of Canada.

Soper, N. J. \& Higgins, A. K. 1991 [issued 1992]: Late Cretaceous - Early Tertiary deformation, North Greenland. In Trettin, H. P. (ed.) Geology of the Innuitian orogen and arctic platform of Canada and Greenland, 461-465. Geology of Canada, no. 3, Chapter 16 (also Geology of North America, Vol. E). Calgary: Geological Survey of Canada. Canada, no.3, Chapter 16 (also Geology of North America, Vol.E). Calgary: Geological Survey of Canada. Geology of Canada, no. 3, Chapter 16 (also Geology of North America, Vol, E). Calgary: Geological Survey of Canada.

Sønderholm, M. 1991: The evolution of the Franklinian carbonate platform (Late Proterozoic? - Silurian), North Greenland. In Bosselini, A. et al. (ed.) Dolomieu Conference on Carbonate Platforms and Dolomitization-Abstracts, 251-253.
Sønderholm, M. \& Jepsen, H. F. 1991: Proterozoic basins of North Greenland. Bull. Grønlands geol. Unders. 160, 49-69.

Steenfelt, A. 1991 [issued 1992]: Economic mineral resources, North Greenland. In Trettin, H. P. (ed.) Geology of the Innuitian orogen and arctic platform of Canada and Greenland, 539-541. Geology of Canada, no. 3, Chapter 20 (also Geology of North America, Vol. E). Calgary: Geological Survey of Canada.

Steenfelt,A. 1991: High-technology metals in alkaline and carbonatitic rocks in Greenland: recognition and exploration. $J$. geochem. Explor. 40, 263-279.

Steenfelt, A. \& Tukiainen, T. 1991: Geochemical mapping: distribution of gold, arsenic, antimony and tantalum in South Greenland. Rapp. Grønlands geol. Unders. 152, 55-61.

Stemmerik, L. \& Håkansson, E. 1991: Carboniferous and Permian history of the Wandel Sea Basin, North Greenland. Bull. Grønlands geol. Unders. 160, 141-151.

Stemmerik, L. \& Piasecki, S. 1991: The Upper Permian of East Greenland - a review. Zbl. Geol. Paläont. Teil 1, 825837.

Stemmerik, L., Christiansen, F. G. \& Piasecki, S. 1991: Evaluation of the hydrocarbon potential onshore North-East Greenland $\left(72^{\circ}-75^{\circ} \mathrm{N}\right)$. Rapp. Grønlands geol. Unders. 152, 13-16.

Stemmerik, L., Christiansen, F. G. \& Piasecki, S. 1990: Carboniferous lacustrine shale in East Greenland - additional source rock on northern North Atlantic? In Katz, B. J. (ed.) Lacustrine basin exploration - case studies and modern analogs. Mem. Amer. Ass. Petrol. Geol. 50, 277-286.

Stemmerik, L., Vigran, J. O. \& Piasecki, S. 1991: Dating of late Paleozoic rifting events in the North Atlantic: New biostratigraphic data from the uppermost Devonian and Carboniferous of East Greenland. Geology 19, 218-221.

Strachan, R. A., Jepsen, H. F. \& Kalsbeek, F. 1991: Regional Caledonian structure of Hertugen af Orléans Land, NorthEast Greenland. Rapp. Gronlands geol. Unders. 152, 95102.

Surlyk, F. 1991: Tectonostratigraphy of North Greenland. Bull. Grønlands geol. Unders. 160, 25-47.

Thomassen, B. 1991: The Black Angel lead-zinc mine 1973-90. Rapp. Grønlands geol. Unders. 152, 46-50.

Thomsen, H. H. \& Olesen, O. B. 1991: Hydraulics and hydrology on the Inland Ice. Rapp. Gronlands geol. Unders. 152, 36-38.

Thomsen, H. H., Olesen, O. B., Braithwaite, R. J. \& Bøggild, C. E. 1991: Ice drilling and mass balance at Pâkitsoq, Jakobshavn, central West Greenland. Rapp. Grønlands geol. Unders. 152, 80-84.

Upton, B. G. J. 1991: Gardar mantle xenoliths: Igdlutalik, South Greenland. Rapp. Grønlands geol. Unders. 150, $37-43$.

Weidick, A. 1991: A change in the status of the Greenland Inland Ice. Rapp. Grønlands geol. Unders. 152, 39-41.

Weidick, A. 1991: Present-day expansion of the southern part of the Inland Ice. Rapp. Gronlands geol. Unders. 152, 73-79. 